\title{
Housing Affordability Factors for Urban Liveability - A Preliminary Study
}

\author{
Elia Syarafina Abdul Shakur, Ahmad Fariz Mohamed \& Abdul Samad Abdul Hadi \\ Institute Environmental and Development (LESTARI) \\ Universiti Kebangsaan Malaysia (UKM) \\ 43600 Bangi, Selangor, Malaysia \\ esyarafina@gmail.com
}

\begin{abstract}
Affordability and homeownership are important factors of urban livability. However, given the rapid increase in house prices and the slower growth of individual incomes in Malaysia, the ability to own a house presents a significant challenge. Rising costs of living add to the problem. Current trends show that housing unaffordability is particularly acute among the middle-income earners, the group that constitutes the main bulk of the Malaysian urban populace. Housing affordability impinges upon urban livability. This paper reports a study that was undertaken to analyse specific factors (namely location, demand, construction costs and service costs) regarding their effects on house prices and housing affordability of the middle-income group. The town of Kajang (Selangor, Malaysia) was chosen as the case study area while the focus is centred on the two most popular segments of residential properties, the single- and double-storey terraced houses. The purpose of this study is to analyse how affordability affects home ownership and to determine its effect towards urban livability. Key findings from this study concluded that there is a link between income and affordability, rapid house price increase affect home ownership and the livability of the middle-income group in the cities in Malaysian.
\end{abstract}

Keywords: Affordability, middle-income, livability, property, homeownership.

\subsection{INTRODUCTION}

Home ownership affordability is a priority indicator adopted by many countries seeking to achieve a better quality of life. Countries such as the United States, United Kingdom, Australia, New Zealand and China put emphasis on their subjects' ability to own a home. Australia has acknowledged the lack of affordable housing over the past two decades (Disney, 2008). According to Milligan et al. (2015), 60\% of tenants in Australia spent more than $30 \%$ of their household incomes on rent in 2009 and 2010 . In addition, the lack of affordable housing and the poor strategic location could pressure on household expenditure.

Malaysian housing sector growth has been fueled by the three major factors, of population growth, rapid urbanisation and economic growth (Wan Nor Azriyati et al., 2011). The ability to own a home is a primary driver for socio-economic stability and the country's development (Zainal Abidin, 2010). It follows that home ownership is one of the aspects for urban livability. For city dwellers to be able to own a home, their incomes must be at a level that supports the ability to purchase it. Based on studies in developed countries, the sum of money to be devoted to home purchase must not exceed a third (1/3) of a household's gross salary (Central Bank of Malaysia 2005). The ability after buying a house is also needed to be considered by homeowners in the future. Hence, the study has identified the key factors that affect the ability for housing ownership towards urban livability.

Home ownership has always been an issue among Malaysians due to insufficient supply of affordable housing (Azalilah, 2015). Affordability is shown to have a high correlation with household and housing 
expenditure and income (Aminahet al. 2015). House prices continue to rise sharply exceeding the ability of the real income of the population, resulting in the inability of most Malaysians to afford their homes. The cost of living is higher than the general price level that causes difficulties for transformation to affordability housing and to ensure sustainable livability in cities. The Central Bank of Malaysia (2014) had expected household expenditures to be affected by the implementation of the Goods and Services Tax (GST) in April 2015, especially for those living in the cities. With this, the middle-income groups face greater problems to own a home because they take up the majority of the city population based on the factors of urbanization (Musa, 2013). Most of them can only afford to rent.

Houses with a strategic location that are near to the city and equipped with amenities are the most sought after by homebuyers (Khazanah Research Institute, 2015). Houses along the main road city and equipped with certain amenities will leads to the increase of house prices (Zainal Abidin, 2010). Jordan Lee \& Jaafar Sdn Bhd (2015) has quoted that unaffordability leads to oversupply in certain locations, which can put downward pressure on prices.

According to New Zealand Productivity Commission (2012), the imbalance between supply and demand is due to the inefficiency in the construction and building industry and some loopholes in the housing law and administration i.e. insufficient lands for housing or delays in the release of lands for housing, or obstructions in planning or agreement. The demand for the medium cost housing units has been increasing (Hamid, 2002), which has tempted developers to take advantage by increasing the house prices as means to gain profits (Kai et al. 2013). The residential property investors also took the opportunity to raise the price of the houses through selling in which they will also gain a profitable amount of return through rental income and capital appreciation (Saw \& Tan, 2014).

In addition, the increase of the prices for construction materials, labour force and design are also speculated to be the main factors for the increase in house price (Hamzah et al. 2011). The cost of building materials is highly dependent on the current market price for the materials. According to Wangui (2014), this building cost determines one's affordability in owning a house. New Zealand Productivity Commission (2012) has stated that GST on the cost of construction materials has caused new house prices to be higher in the market. GST is also included in the cost of additions or renovations, repairs and maintenance throughout the life of a house.

Public services can be funded through service cost (Bel \& Miralles 2010). Herbert et al. (2013) mentioned that one of the costs effective approaches to owning a house is by stabilizing property values through taxation, maintenance and transaction cost. Bird \& Slack (2004) argued that a tax on an area are within the same size and of the same amount regardless whether the taxpayers are in high income or low-income bracket. Even old properties in need of maintenance are also taxable due to their large floor area. Connolly \& Bell (2008) proposed that properties should be taxed based on location and affordability of the property buyers. According to Yang (2009), limitations on property taxes may have impacts on the decision made by homebuyers; for example whether or not to back out from house purchase.

Since home maintenance services are connected to homeownership, the concept of 'bandar dayahuni' or livable city was introduced in Malaysia. This concept, according to Federal Department of Town and Country Planning (2011), refers to a settlement with standards and services that improve the residents' quality of life. Abdul Samad et al. (2014) stated that these standards and services, i.e. the affordable new houses and the continuous improvements on infrastructures related to health, education, modern transportation, physical infrastructures, and recreational amenities, are social projects funded by local and foreign investors to ensure the quality of life among the urbanites.

A livable city is a place for everyone. Unfortunately, there are people earning money in the vicinity yet living in the surrounding communities or outside the city due to affordability issues. (Hahlweg 1997; Timmer \& Seymoar 2005). Accessibility to amenities and infrastructures is a central factor in achieving 
livabilities such as shops, offices, schools and others, and also important in ensuring its future economic performance (Cities Alliance 2007).

\subsection{DATA AND METHODS}

This study uses secondary data from Statistic Department of Malaysia, Selangor Housing and Property Board, Department of Valuation \& Property Management, Kajang Municipal Council, Quantity Surveyors Malaysia (JUBM) and Langdon Seah. Prior to this, a field observation was conducted for three main purposes; 1) to verify the secondary data, 2) to understand the development process such as housing projects and mega projects such as the MRT Kajang station construction, and 3) to determine the implication of urbanisation process on the affordability housing issues especially to the middle-income group in Kajang town. The trend analysis for population growth, the increase in house prices, the rise of construction costs and a number of the housing project by categories provide an overview on the issue of affordability for home ownership. The impact of home ownership affordability will affect the livability for the urban dwellers. An analysis of the key factors was conducted to uncover the affordability effect on the values and pricing of a house. This key factors includes location, demands, construction costs and services costs in Kajang Town. However, this paper aims to achieve the following: 1) to identify key factors that affect house price increase and identify how the price increase affect affordability and 2) to identify how affordability affect the livability.

\subsection{URBANISATION IN THE KAJANG TOWN}

The study was conducted in Kajang sub-district, which falls under the administration of Hulu Langat District in the State of Selangor. Kajang town in 1970 was recognized as 'Pekan Kajang' and has now become an urbanized area named 'Bandar Kajang'. It is strategically located about 20km from the city of Kuala Lumpur and Putrajaya (See Map 1). Kajang town has been experiencing rapid urban growth for the past twenty years and is still growing. The town is equipped with basic services such as schools, banks, and shopping centers, to name a few. The new development brings in important infrastructures such as Mass Rapid Transit (MRT) and better highways and roads to Kajang town. According to AllianceDBS (2014), the three MRT stations within Kajang have prompted several public-listed property developers and other major developers such as SP Setia, Mah Sing, UEM Sunrise, Eco World, and Tropicana to purchase the lands in the area. These new developments also offer affordable properties as well as available infrastructures which are as follows:

(i) Education hub: there are several primary and secondary schools in the vicinity such as Convent Kajang, Yu Hua Kajang, and education institutions, including New Era University College, Universiti Kebangsaan Malaysia, Nottingham University campus, the German Malaysia Institute, and the Australia International School.

(ii) Easy access with the opening of several highways that link Kajang/Semenyih to other major townships within Klang Valley. These include the Kajang SILK Highway and Persiaran KajangSemenyih. Other links to the area are Lebuhraya Utara Selatan, Cheras-Kajang Highway and Lebuhraya Klang Selatan. 


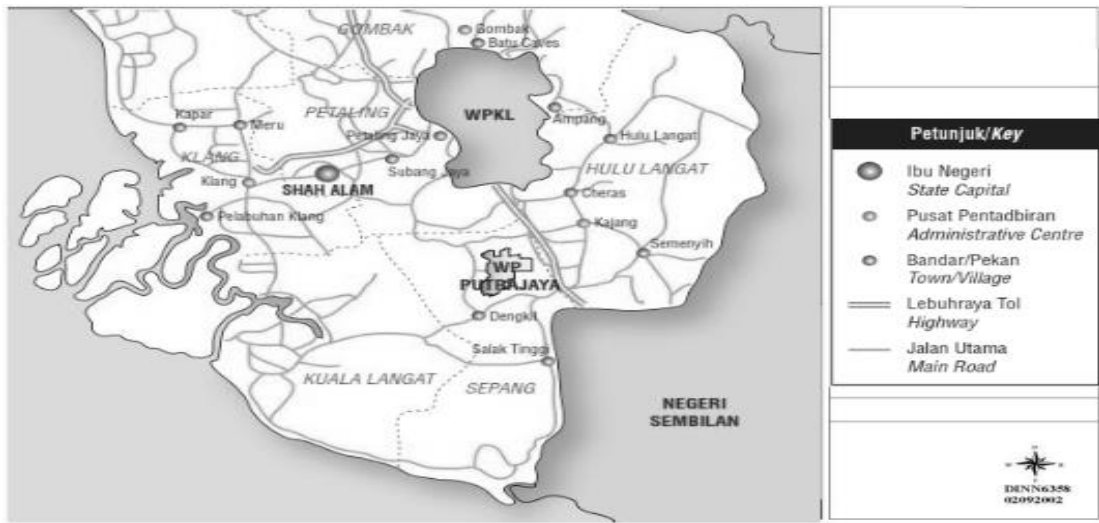

Map 1: The Kajang Town Location Between Kuala Lumpur and Putrajaya Source: Department of Valuation \& Property Services (2014)

According to the Kajang Municipal Council, the population in Kajang is increasing dramatically and becoming a challenge to the management of the municipality. Since 1970, migration of people from rural to urban areas has created a high demand and supply especially in residential sectors. According to Zainal Abidin (2000), the economic development in Selangor has created many job opportunities through many development projects. Hence, many people choose to migrate to Selangor. Table 1 shows the population growth trend in Kajang town.

Table 1: Population Growth in Kajang Town

\begin{tabular}{ccccccc}
\hline Year & $\mathbf{1 9 9 1}$ & $\mathbf{1 9 9 9}$ & $\mathbf{2 0 0 0}$ & $\mathbf{2 0 0 4}$ & $\mathbf{2 0 0 9}$ & $\mathbf{2 0 1 4}$ \\
\hline $\begin{array}{l}\text { Number of } \\
\text { Population }\end{array}$ & 46,269 & 83,989 & 86,072 & 104,165 & 110,192 & 117,543 \\
\hline \multicolumn{5}{l}{ Source: Department of Statistics (2000); Selangor Housing and Property Board (2014) }
\end{tabular}

Most of the land tenure in Kajang is freehold. Many residents prefer to buy houses in freehold areas. One of the advantages of owning freehold property is the security of tenure. The rise of the population (see Table 2) has led to the increase of housing area every year in Kajang town. The increase in demand can be seen in Table 3 which shows the number of residential units by category: low-cost, medium-cost and high-cost houses for the years 2009 and 2014.

Table 2: Housing Trends in The Kajang Town

\begin{tabular}{ccccccc}
\hline Year & $\mathbf{1 9 9 1}$ & $\mathbf{1 9 9 9}$ & $\mathbf{2 0 0 0}$ & $\mathbf{2 0 0 4}$ & $\mathbf{2 0 0 9}$ & $\mathbf{2 0 1 4}$ \\
\hline $\begin{array}{c}\text { Number of } \\
\text { Transactions }\end{array}$ & 12,079 & 19,308 & 23,160 & 25,406 & 26,876 & 29,386 \\
\hline
\end{tabular}

Source: Department of Statistics (2000); Selangor Housing and Property Board (2014)

Table 3: Housing Project Under Construction in the Kajang Town

\begin{tabular}{|c|c|c|c|c|c|c|c|c|}
\hline \multirow[t]{2}{*}{ Zone } & \multirow{2}{*}{$\begin{array}{c}(+) \\
\text { UNIT } \\
2009\end{array}$} & \multicolumn{3}{|c|}{$\begin{array}{l}\text { SUBDIVISION OF } \\
\text { HOUSING UNITS }\end{array}$} & \multirow{2}{*}{$\begin{array}{c}(+) \\
\text { UNIT } \\
2014\end{array}$} & \multicolumn{3}{|c|}{$\begin{array}{l}\text { SUBDIVISION OF } \\
\text { HOUSING UNITS }\end{array}$} \\
\hline & & LOW & MIDDLE & HIGH & & LOW & MIDDLE & HIGH \\
\hline Kajang & 1,470 & 441 & 735 & 294 & 2,510 & 753 & 1,255 & 502 \\
\hline
\end{tabular}

Source: Estimate Selangor Housing and Property Board (2014) 
Each municipality in Selangor strives to meet housing demands which cover from all levels of income. Table 4 shows the number of housing units according to the category by 'Majlis Perbandaran Kajang' (Kajang Municipal Council). However, high-cost housing units are higher in demand as compared to other types of units. Housing needs on demand and supply are in imbalance as the majority of those who live in the city are from the middle-income group. In addition, private developers appear to be more attracted to making profits rather than addressing affordability to home buyers through the development of three-storey houses, semi-detached and bungalows in Kajang.

Table 4: Housing supply by Majlis Perbandaran Kajang, Selangor (2007- September 2012)

\begin{tabular}{lccccc}
\hline \multicolumn{1}{c}{ Local authority } & \multicolumn{5}{c}{ Type of public housing } \\
\cline { 2 - 5 } & $\begin{array}{c}\text { Low-cost } \\
\text { housing }\end{array}$ & $\begin{array}{c}\text { Low-medium- } \\
\text { cost housing }\end{array}$ & $\begin{array}{c}\text { Medium- cost } \\
\text { housing }\end{array}$ & $\begin{array}{c}\text { High-cost } \\
\text { housing }\end{array}$ & Total \\
\hline $\begin{array}{l}\text { Majlis Perbandaran } \\
\text { Kajang }\end{array}$ & 268 & 204 & 604 & 2,436 & 3,512 \\
\hline
\end{tabular}

Source: Selangor Housing and Property Board

\subsection{FACTORS THAT AFFECT THE PRICING OF THE HOUSE IN KAJANG}

House price is influenced by economic factors, such as real income growth, interest rate, stock prices, supply, population growth and economic activity (Zainal Abidin, 2010). This study has drawn on four (4) factors that have an influence on house prices in Kajang i.e. location, demands, the cost of construction, and cost of services (Hamzah et al. 2011; Muhammad 2012; AllianceDBS 2014; Jordan Lee \& Jaafar Sdn Bhd 2015). Discussions on the four factors as mentioned by Zainal Abidin (2010) are more closely applicable to the current situation in Kajang which can be summarised as follows:

\section{a. Location and Demand}

Most people prefer to stay in Kajang town as it is provided with infrastructures and burst with economic activities. As a result, the demand for housing is high which caused expensive houses to be offered for sale. Therefore, it has become a challenge for the middle-income groups to own a house, especially for graduates who have just started working.(Musa 2013). Since the majority of the housing parks in Kajang were built in 1970, this has affected the supply of affordable housing which has become limited. The increase of land values and housing demands in Kajang area have caused developers to build high-rise projects to "optimize yields" (gross development) (AllianceDBS, 2014). (See Table 5)

Table 5: Huge differences in land price between North and South of KL for parcels near MRT stations

\begin{tabular}{lccl}
\hline Area & $\begin{array}{c}\text { Estimate land price } \\
\text { RM psf }\end{array}$ & $\begin{array}{c}\text { Estimate property ASP } \\
\text { RM psf }\end{array}$ & Developer \\
\hline Sg. Buloh & $200-300$ & $600-700$ & Mah Sing, Selangor \\
& & & Dredging \\
Kota Damansara & $200-300$ & $600-700$ & Media Inc \\
$\begin{array}{l}\text { Pusat Bandar } \\
\text { Damansara }\end{array}$ & $1300-1800$ & 1450 & Guoco Land \\
Dataran Sunway & $350-450$ & $1000-1200$ & Tropicana \\
Kajang city & $80-100$ & $350-450$ & MKH \\
\hline \multicolumn{2}{r}{} \\
\end{tabular}

Table 5 shows the areas that were formerly located in the suburbs but currently are within the city called 'Greater KL'. For example, Sg. Buloh was a rubber plantation and a rural area before 1996. With the Mass Rapid Transit (MRT) connectivity, which is expected to be completed in 2017, and state-of-the-art 
infrastructures, also with several highways, Kajang area has become the preferred choice for developers to expand township developments. Strategic location and high demand have an influence on the increase in land and house prices. Furthermore, Kajang is a strategic location for investment as property prices are still affordable. However, there are investors who purchase properties for capital gains which limit the opportunities of first home buyers to own a home as their place of residence.

\section{Price Movement Two Storey Terrace House}

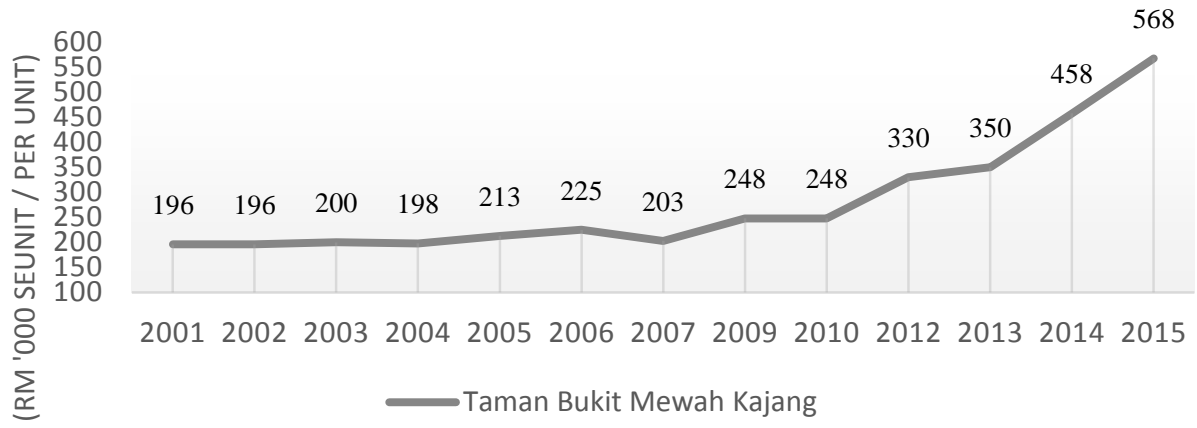

Figures 1: Rising House Prices

Source. Department of Valuation \& Property Services

This phenomenon can be seen in Taman Bukit Mewah which is one of the areas located near the MRT station (under construction), and also within short distance to the many government agency offices, especially the Kajang Municipal office. In addition, this housing area is also surrounded by public facilities that are easily accessible. Based on the statistical data from the Department of Valuation and Property Management (Figure 1), the price of double-storey terrace houses increases every year in Taman Bukit Mewah, Kajang. According to Nor Malina (2012), those from the middle-income group whose income ranges between RM2, 500 to RM7, 000 are still uncertain to buy a home. The majority of this group are only able to buy a house priced between RM50, 000 to RM200, 000.

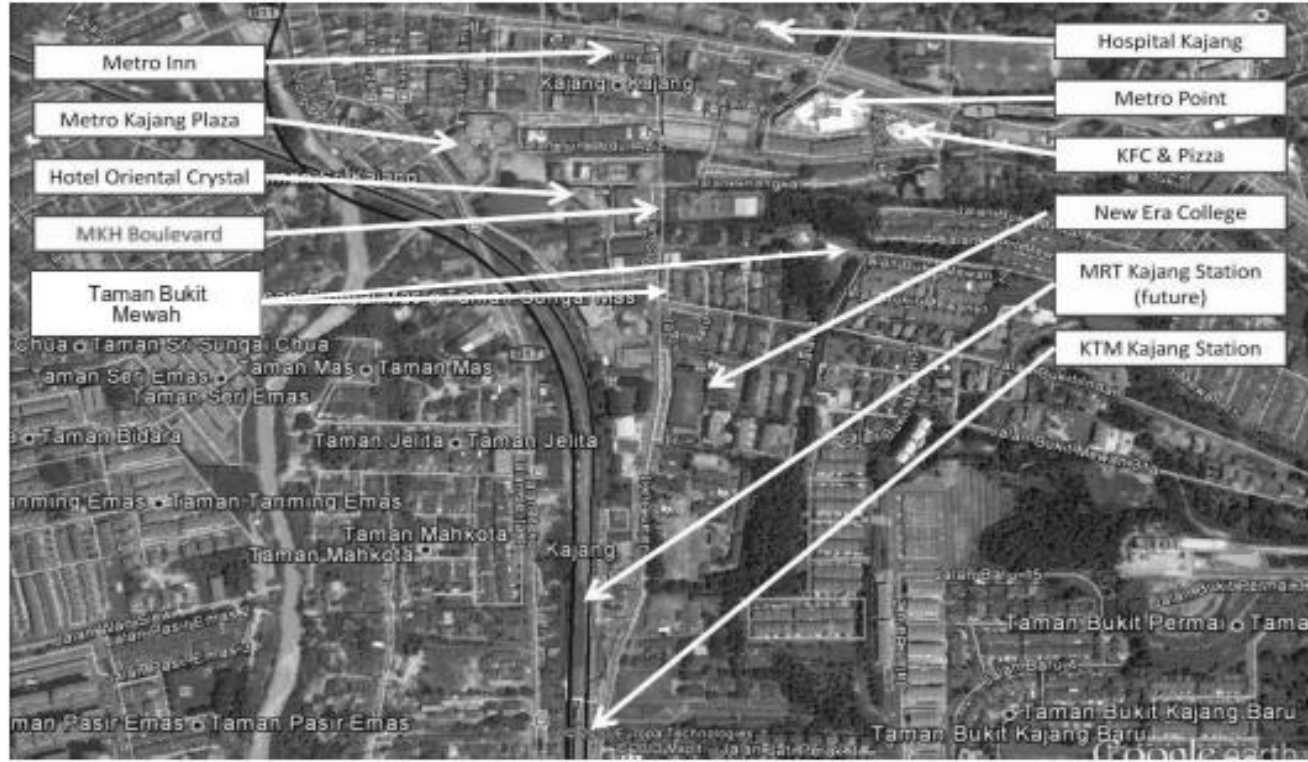

Map 2: The Part of Kajang Town and Location of MRT Kajang Station (Future) Source: Metro Kajang Holding (MKH) (2015)

According to Zainal Abidin (2000), residential properties can be transferred as an inheritance or sale. Based on Table 6, many people have bought properties in secondary market rather than from developers. It is 
possible that several housing prices are still affordable offered by willing sellers based on transactions recorded by the Valuation \& Property Services Department. According to Bank Negara Malaysia (2012), about $80 \%$ of real estate transactions meet the demands of the country's population through the secondary market. In 2014, the number of transfers from developers decreased by 7.1\%. However, the value of transactions in 2014 increased by $4.3 \%$ means shows that, on average, developers' prices had increased.

Table 6: Number of Property Transactions by Category of Transferor and Transferee in Selangor

\begin{tabular}{ccccc}
\hline Year & \multicolumn{2}{c}{ Individual \& Individual } & \multicolumn{2}{c}{ Developer \& Individual } \\
\cline { 2 - 5 } & Number & $\begin{array}{c}\text { Value } \\
\text { (RM Million) }\end{array}$ & Number & $\begin{array}{c}\text { Value } \\
\text { (RM Million) }\end{array}$ \\
\hline $\mathbf{2 0 1 2}$ & 47,169 & $15,137.27$ & 14,181 & $5,200.64$ \\
$\mathbf{2 0 1 3}$ & 47,540 & $17,363.29$ & 5,567 & 3659.93 \\
$\mathbf{2 0 1 4}{ }^{\text {P }}$ & 46,422 & $18,098.09$ & 5,171 & $3,816.12$ \\
\hline
\end{tabular}

Source: Valuation and Property Services Department (2014)

Transaction costs vary among countries and the countries that have the highest percentage of 14 percent of the property value are Greece, France and Belgium. Meanwhile, the lowest percentage of below 4 percent was recorded in Denmark (Bentzien 2012). In Malaysia, the down-payment for the purchase of a house as one of the transaction cost is 10 percent of the total house price. For example, a house priced at RM400,000 has a down-payment of RM40,000. According to Bentzien (2012), home ownership has been difficult for young households as it takes them a long period to save for the down-payment. Difficulty in saving for initial capital seemingly opened up a widening gap (in proportion) between the units offered and the units taken up, as suggested by data in Table 7 .

Table 7: Launched and Unsold Residential Units in Selangor

\begin{tabular}{cccc}
\hline Year & $\begin{array}{c}\text { Launched } \\
\text { Units }\end{array}$ & $\begin{array}{c}\text { Unsold } \\
\text { Units }\end{array}$ & Value (RM Milion) \\
\hline $\mathbf{2 0 1 2}$ & 15,281 & 2,709 & $1,233.31$ \\
$\mathbf{2 0 1 3}$ & 9,941 & 1,750 & $1,073.24$ \\
$\mathbf{2 0 1 4}$ & 7,583 & 1,889 & 941.29 \\
\hline
\end{tabular}

Source: Valuation and Property Services Department (2014)

The table above shows the launch of the new housing units and the number of unsold units. Residential units overhang indicated the number of increase, up to $7.9 \%$ in the number to 1,889 units though the depreciation of RM941.29 down $12.3 \%$ in 2014. Most overhang units were mainly the stratified units, such as low-cost flats. This was probably due to the prices offered that are higher or similar to the price of the landed house in the surrounding area. The middle-income earners are not eligible for the low-cost units because of their higher-than-the-threshold incomes. Neither can they buy the standard units, which have become too expensive to be affordable. In fact, the standard units are sold at prices higher than what this group's incomes can afford.

\section{b. Cost of construction}

The rising construction is also seen as one of the challenges with respect to house prices in Kajang. Figure 2 shows the construction costs trend in Kuala Lumpur by type of houses which, because of its comparability, provides a good measure of the trend for Kajang. According to Alliance DBS (2014), the costpush factors such as rising construction cost and the implementation of Goods \& Services Tax (GST) will continue to put pressure on material construction prices. New tenders for construction contracts have seen higher quotations. As a result, there are competitions between contractors regarding prices on raw materials and labour rate. With the increase of material production and processing price, contractors could not afford to withstand the rise of material price that forced them to raise the selling price of their finished unit (Cindy \& 
Haron, 2013). Meanwhile, the building material cost should be sensitive towards ecological concerns. According to Oktay (2014), local or imported building materials used should suit the weather and surroundings. They have to be adaptable to changes through time which ability to adopt bring positive impacts to the residents' well-being and security when there is no need for short-term maintenance and upgrading costs. For labour cost, the use of Industrialized Building System (Sistem Bangunan Berindustri ) may cut down labour use by 30 to 40 percent, thereby reducing the building cost of a house (Nathan, 2016).

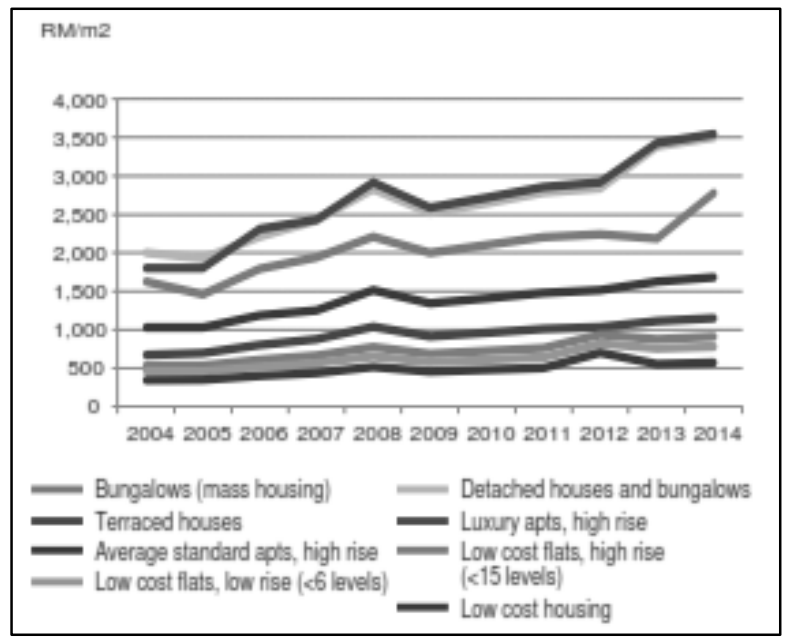

Figure 2: Kuala Lumpur Construction Cost Trend 2004 - 2014 Source: Langdon Seah (2015)

Property developers have started to raise the selling prices for new housing projects after factoring in GST. Australia has also implemented the GST on the cost of construction for a new home. As a result, the first home buyers had to buy a house priced 'under the GST' (Guest, 2005). According to Bentzien et al. (2012), Germany has the highest construction costs than other European countries. For example, the German detached houses are more expensive (5.6 times average annual household income) than the United Kingdom (3.4 times).

Other challenges would be the increasing compliance cost that is required to provide housing quota by Bumiputera and non-Bumiputera. Ismail et al. (2015) have observed that most of the high cost or expensive housing units allocated for the bumiputera lot quota failed to be sold. Following Selangor Housing and Property Board (2014), the policy includes bumi discount/quota (5-15\% / 30-60\% depending on location and land status), low-medium cost housing quota (30-50\% depending on land size), and government reserve or public area, which have led to cross-subsidy of products. The developer must incur a loss of more than RM100,000 per unit in estimation for every low-cost house built with a capital of RM42,000 for the implementation of the this policy (AllianceDBS, 2014). However, the capital remained high despite the increase in construction costs. According to Ismail et al. (2015), some developers take advantage by raising the price of houses that even the Bumiputera cannot afford to purchase despite having the bumiputera quota.

\section{c. Cost of services}

In order to maintain house ownership, buyers would have to bear additional payment service costs that include assessment tax and property tax. In Malaysia, assessment tax is imposed by local authority based on the annual rental value of property. In Kajang, the rate is determined by Majlis Perbandaran Kajang currently at $8.8 \%$ for residential units that are categorized as developed urban area (See Table 8). 
Table 8: Examples of Assessment Tax in Taman Kajang Jaya

\begin{tabular}{cccccc}
\hline Type of House & $\begin{array}{c}\text { Size } \\
\text { Lot }\end{array}$ & Street & $\begin{array}{c}\text { Annual Rental } \\
\text { Value/ } \\
\text { per annum (RM) }\end{array}$ & $\begin{array}{c}\text { Percentage } \\
\text { of Rate } \\
(\%)\end{array}$ & $\begin{array}{c}\text { Annual } \\
\text { Assessment Tax/ } \\
\text { per annum (RM) }\end{array}$ \\
\hline $\begin{array}{c}\text { Two-storey Terrace } \\
\text { (Corner Lot) }\end{array}$ & $151 \mathrm{sm}$ & $\begin{array}{c}\text { Kajang Jaya } \\
4\end{array}$ & 3,350 & 8.8 & RM 294.80 \\
$\begin{array}{c}\text { Two-storey Terrace } \\
\text { (Middle Lot) }\end{array}$ & $149 \mathrm{sm}$ & $\begin{array}{c}\text { Kajang Jaya } \\
4\end{array}$ & 3,120 & 8.8 & RM 274.56 \\
\hline
\end{tabular}

Source: Majlis Perbandaran Kajang (2015)

Assessment tax is to cover expenses for services and development such as garbage collection, construction and maintenance of public infrastructure, and greenery maintenance. The property tax is imposed to finance construction, maintenance of public facilities, infrastructure and street lights. However, tax collection in Malaysia is an issue due to a high rate of arrears in property taxes. According to Muhammad et al. (2012), the most significant variables are the 'need and ability by taxpayers' related to the 'perceptions of fairness of the tax system'. However, assessment taxes paid did not explicitly specify the type of services delivered, which lead to taxpayer's dissatisfaction. Their argument was related to the poor service provided by the Local Government that did not reflect the rates paid. This argument of unfairness regarding payment system arose since the assessment tax rate was valued based on the size of land and type of houses. The unfairness of the tax system may reflect taxpayer's perceptions that they are overpaying taxes regardless of the value of the services provided by the government or about what other taxpayers are paying. Since tax payments that are not in line with the services provided by the local authority, the ability and comfort of homeowners and renters are affected. Residents had to spend additional costs to ensure that they are provided with the necessary services such as security (e.g. CCTV installations), cleanliness (e.g. hiring cleaning) and health (e.g. treatment costs, such as dengue), public transport (eg. freight costs) and traffic congestion.

\subsection{HOUSE AFFORDABILITY FOR URBAN LIVABILITY}

Housing Affordability and Livability Agenda (HALA) Advisory Committee (2015) have mentioned that the supply of affordable housing is the lifeblood of culturally rich, various, and livable urban centers. Without all of this, people who work in cities will be forced to move out, creating negative impacts not only on individual lives, but also on other aspects which include more traffic congestion, increased environmental degradation, and fragmentation of communities. Housing affordability must remain a cornerstone of each city's commitment such as 'Seattle home' agenda in Washington to ensure a fundamental fairness for each individual and community.

Urban livability is defined as a township that gives priorities to the needs of the residents (Song 2011). It offers balance by providing affordable houses in each location and efficacy in transportation, to fulfil the demands of home choices for all ages, incomes, and races, to reduce the combined housing and transportation cost burdens (US Environmental Protection Agency 2011).

Federal Department of Town and Country Planning (2011) have put forward the concept of urban livability as an area with a strategic location that will allow for mixed use and the ability to provide for many people, flexible and easily responsive to changes. According to HALA Advisory Committee (2015), for the promotion of livability, the planning for new housing is led by the values of equity and sustainability to create resilient communities that are provided with good transportation choices, open space and facilities that will ensure a good quality of life for all. 
Housing affordability on the other hand, is described by Stone et al (2011) as not only affordability in terms of household income but also in terms of mortgage affordability, non-housing expenditures, and current housing wealth. Affordability of home ownership is one aspect of livability in a city. Livabilty reflects the well-being of the population; a dwelling for the present and future (Victorian Competition and Efficiency Commission, 2008), especially in the city. Abdul Samad et al. (2008) described the livable concept where a city provides housing options consistent with affordability, job opportunities, comprehensive and easy accessibility to socialize. Urban residents will be able to live their daily life with safety, healthy and vibrancy (Shaharudin et al 2010). The government and private sectors have to make an effort to increase the number of affordable housing units by increasing supplies. A sharp rise in house prices without the support of firm fundamentals such as income growth, increase in population, accommodative monetary policy, and low unemployment rate could lead to artificial house price bubble (Zainal Abidin, 2010).

In relation to construction cost, Parker (2015) have highlighted two criteria which need to be emphasised for livability namely, making design and construction easier (such as 'omit excessive restrictions on design unless benefits exceed costs') and residential construction productivity and supply (such as 'development at scale to support more competitive industry structure and regulatory reform to transform the structure, conduct and performance of the residential construction market'). The concept is for the community needs rather than developer. For example, Majlis Perbandaran Kajang should exclude immoderate restrictions on design unless the benefits exceed costs. The authorities should guide the development at scale to support more industry structure and regulatory reform so as to change the structure, conduct and performance for the needs of the residential construction market

Lastly, with regards to service cost, municipal council should be improve accessibility to achieve livability. For example, transit-oriented development should be highly accessible to all including disabilities which would encourage people to use of public transportation (Federal Department of Town and Country Planning, 2011). Majlis Perbandaran Kajang (2013) has provision in its plans towards urban livability namely through the 'Strategic Plan in 2009-2013' to create township to be comfortable, safe, developed and active in Kajang town.

According to Parker (2015), to achieve the home affordability target in Auckland, the roles of city council and the government which include collaborative review of transport policy to ensure it supports housing growth and transport planning system which should be responsive to growth demand. Local government should be sharing in revenue based on economic activity to help pay for infrastructure and service, and help incentivise local communities towards growth. Likewise, this approach can be applicable in the study area.

The $10^{\text {th }}$ Malaysian Plan has targeted to provide comfortable, satisfactory, quality and affordable housing with inclusive facilities and conducive environment for a livable city. This planning can help improve the sustainability of quality of life, increase the capability and accessibility for people to own or rent a home; and to set future directions for ensuring the sustainability of housing (Aminah et al., 2015). Hence, the government and the private sectors should take into consideration the views of the population on the development of the city (Abdul et al. 2008). The opinions of residents are required to improve the basic facilities especially in the aspects of reducing the cost of living and cost of all services. The support and participation of the population with the programs organized are also required to increase social unity and livability. .

\subsection{CONCLUSION}

In conclusion, the key factors as to determine the linkages and effects of house or property value to the ability of homeownership. One of the key findings in this study is that there is a link between income and affordability, while the rapid growth of demand and prices affects the ownership and the livability of the middle-income group in Malaysian cities ability to have an initial capital for new a young buyer is important. The results of the study will assist to the development of strategies for affordable housing and the ability to 
remain sustainable for living in urban areas. When the observations been conducted, this may reflect that Kajang Town is a strategic location which near to highway and easily went to work either by public transportation or private vehicles. It also in demand because providing for job opportunities and land of mixuse (eg housing of variety, shopping mall). Many constructions still in progress such as housing and MRT station which adaptability for developer and contractor to built affordable house is critical. Therefore, developers should think cost of construction with more innovation by the restructuring of system to cut the cost of housing (eg the use of Industrialized Building System). Lastly, cost of services which is to support communities (e.g preservation of housing, maintenance, cleaning, health, and safety) that ensure a good quality of life for all residents in Kajang. This study is an effort to ensure that the Government and the developer can help communities in Malaysia, especially the middle-income group. This research hope to achieve the aim of homeownership affordability for liveable city or community.

\subsection{REFERENCE}

Abdul Samad Hadi, Shaharudin Idrus, Abdul Hadi Harman Shah \& Ahmad Fariz Mohamed. (2008). Dayahuni bandar (Urban Livability). Bangi: Lestari Universiti Kebangsaan Malaysia Press.

Abdul Samad Hadi, Abdul Hadi Harman Shah, Shaharudin Idrus \& Ahmad Fariz Mohamed. (2014). Opportunities for security governance in the face of local safety crisis. In Mira, R. G. \& Dumitru, A. Urban Sustainability Innovative Spaces, Vulnerabilities and Opportunities. The 6th International Symposium on "Sustainable Environments in a Changing Global Context" at A Coruña, Spain in 25- 28 June 2013, pp 33- 48

Abdul Rahman Embong. (2011). Urbanisation and Urban Life in Peninsular Malaysia. Akademika, 81(2), 23 39

Abdul Hamid Mar Iman. (2002). An Introduction to Property Marketing. Skudai: Universiti Teknologi Malaysia Press.

Aminah Md Yusof, Chai, C.S. \& Johan, J. (2015). Urban Poor and Housing Affordability in Malaysia. In Zheng, D. (Eds.). Information Engineering and Education Science. London: Taylor \& Francis Group

AllianceDBS. (2014). Malaysia Industry Focus Property. AllianceDBS Research Sdn Bhd

Azalilah Ramdani Musa, Norganiny Mohd Tawil, Adi Irfan Che-Ani \& Hassan Basri. (2015). An Analysis of the Selection Criteria in Purchasing a House in Klang Valley towards the Quality Affordable Housing. Life Science Journal, 12(2), $51-57$.

Azalilah Ramdani Musa, Norganiny Mohd Tawil, Adi Irfan Che-Ani, Hassan Basri, \& Mokhtar, M. A. (2013). Designing Basic Housing Floor Plan to Solve House Pricing Issue for Middle-Income Citizens. International Business Management, 7(3), 208 - 213.

Bel, G. \& Miralles, A. (2010). Choosing between service fees and budget funding to pay for local services: empirical evidence from Spain. Environmental and Planning C: Government and Policy, 28, 54-71.

Bentzien, V., Rottke, N. \& Zietz, J. (2012). Affordability and Germany's low homeownership rate. International Journal of Housing Markets and Analysis, 5(3), 289-312.

Bird, R.M, \& Slack, E. (2004). (Eds.). International Handbook on Land and Property Taxation. Cheltenham, UK: Edward Elgar Publishing Inc. 
Central Bank of Malaysia, BNM. (2005). Looking for a Housing Loan. Retrieved December 12, 2013. Websites: www.bankinginfo.com.my.

Central Bank of Malaysia, BNM. (2012). Laporan Kestabilan Kewangan Dan Sistem Pembiayaan 2012. Bank Negara Malaysia.

Central Bank of Malaysia, BNM. (2014). Prospek dan Dasar Pada Tahun 2015. Bank Negara Malaysia.

Cindy, L. \& Nuzul Azam Haron. (2013). Factors Influencing The Rise Of House Price In Klang. International Journal of Research in Engineering and Technology, 2(10), 261-272.

Cities Alliance. (2007). Liveable Cities: The Benefits of Urban Environmental Planning. Washington D.C.

Connolly, K., \& Bell, M. (2008). Financing Urban Government in Transition Countries: Assessment Uniformity and the Property Tax. Environment and Planning C: Government and Policy, 28(6), 978-991.

Department of Statistics. (2000). Laporan Am Banci Penduduk. (Population Cencus Report) Kuala Lumpur. Department of Statistics Malaysia.

Disney, J. (2007). Affordable Housing In Australia: Some Key Problems and Priorities for Action. National Forum on Affordable Housing, Australian Housing and Urban Research Institute.

Federal Department of Town and Country Planning. (2011). Compact city vs Vibrant and Livable Cities. Retrieved Disember 16, 2014.

Website:http://www.epu.gov.my/c/document_library/get file?uuid=280f12a1-a3f7-4014-9eec$\underline{3 b f 4860 \mathrm{c} 7687 \& \text { groupId }=283545}$

Guest, R. S. A. (2005). Life Cycle Analysis of Housing Affordability Options for First Home OwnerOccupiers in Australia. Economic Record, 81(254), 237 - 248

Hahlweg, D. (1997). The City as a Family. In Making Cities Livable. International Making Cities Livable Conferences. California, USA: Godolier Press.

Hospital Kajang. (2015). Sejarah. Retrieved April 20, 2015, Websites: http://hkig.moh.gov.my/index.php?option=com content\&view=article\&id=5\&Itemid=9\&lang=ms

Housing Affordability and Livability Agenda Advisory Committee (HALA). (2015). Seattle Housing Affordability and Livability Agenda. Retrieved Mei 20, 2016, Websites: http://murray.seattle.gov/wpcontent/uploads/2015/07/HALA_Report_2015.pdf.

Hamzah, N., Khoiry, M. A., Ali, M. A. M., Zaini, N. S. \& Arshad, I. (2011). Faktor luaran dan dalaman yang mempengaruhi harga rumah teres di Bandar Baru Bangi. J. Design Built, 4, 1-8.

Ismail, A., Bujang, A. A., Anthony Jiram, W. R., Abu Zarin, H. and Jaafar, M. N. (2015). Factor Affecting the Housing Financing of Bumiputera in Iskandar Malaysia. Journal of Economics, Business and Management, 3(11), 1031-1036.

Jordan Lee \& Jaafar Sdn Bhd. (2015). Factors affecting prices. Retrieved September 19, 2015, Websites: http://www.thestar.com.my/business/business-news/2015/12/19/factors-affecting-prices/

Khazanah Research Institute. (2015). Making Housing Affordable. Kuala Lumpur: Khazanah Research Institute. 
Kai, C. G., Ta, W. S., \& Hui H. G. (2013). Challenges of implementing Sustainability in Malaysian Housing Industry. In: International Conference on Sustainable Built Environment for Now and the Future (SBE2013), 26-27 March 2013, Hanoi.

Langdon Seah. (2015). Construction Cost Handbook Malaysia 2015. Langdon \& Seah Sdn Bhd.

Selangor Housing and Property Board, LPHS. (2014). 'BLUE PRINT' Perumahan Negeri Selangor Darul Ehsan (2004 - 2014). Lembaga Perumahan dan Hartanah Selangor (LPHS)

Oktay, D. (2014). Towards Human Sustainable Urbanism: Interrogating The Contemporary Approaches And The Traditional Turkish (Ottoman) City. In Mira, R. G. \& Dumitru, A. (2014). Urban Sustainability Innovative Spaces, Vulnerabilities and Opportunities. 6th International Symposium on "Sustainable Environments in a Changing Global Context” at A Coruña, Spain in 25- 28 June 2013. pp 33- 48.

Majlis Perbandaran Kajang. (2013). Pelan Strategik 2009-2013. Majlis Perbandaran Kajang. Retrieved November 2, 2014, Websites: www.mpkj.gov.my/.../Pelan Strategik_MPKj_23.pdf

Majlis Perbandaran Kajang. (2015). Kenyataan Tuntutan Cukai Taksiran dan Lain-lain Caj. Retrieved November 16, 2015. http://public.mpkj.gov.my/etaksiran/default.asp?MN=3

Ministry of Housing and Local Government. (2011). National Housing Policy. Department of Housing, Ministry of Housing and Local Government, Putrajaya.

Milligan, V., Pawson, H., Williams, P. \& Yates, J. (2015). Next moves? Expanding Affordable Rental Housing In Australia Through Institutional Investment City Futures Research Centre, UNSW Australia. ISBN 978-0-9942898-0-3

Muhammad Akilu Umar, Rozilah Kasim \& Martin, D. (2012). An Overview of Property Tax Collection As A Tool For A Sustainable Local Government Reform In Malaysia. Proceedings International Conference of Technology Management, Business and Entrepreneurship (ICTEMB2012), Renaissance Hotel, Melaka, Malaysia, 18-19 Dec 2012. pp 593-605

Malina Malek, Nor \& Azrina Husin. (2012). "Pemilikan Rumah dalam Kalangan Masyarakat Bandar Berpendapatan Sederhana dan Rendah di Malaysia "SOSIOHUMANIKA: Jurnal Pendidikan Sains Sosial dan Kemanusiaan, 5(2), 269-284.

New Zealand Productivity Commission. (2012). Housing Affordability- Final Report. Retrieved April 15, 2014, Websites:

http://www.productivity.govt.nz/inquiry-report/housing-affordability-final-report.

Parker, C. (2015). Housing Supply, Choice and Affrdability: Trends, economic drivers, and possible policy interventions. Auckland Council. Retrieved May 21, 2016, Websites:

http://www.aucklandcouncil.govt.nz/EN/AboutCouncil/businessandeconomy/Documents/housingsupplyc hoiceandaffordability.pdf

Saw, L. S. \& Tan, Teck Hong. (2014). Factors Affecting the Purchase Decision of Investors in the Residential Property Market in Malaysia. Journal of Surveying, Construction and Property, 5(2), 1-13.

Song, Y. (2011). A Livable City Study in China Using Structural Equation Models. Master Thesis in Uppsala University. 
Stone, M., Burke, T., \& Ralston, L. (2011). The Residual Income Approach to Housing Affordability: The Theory and the Practice. Australian Housing and Urban Research Institute: Community Studies Faculty Publication Series.

Timmer, V., \& Seymoar, N. K. (2005). The Livable City. The World Urban Forum 2006. Vancouver Working Group Discussion Paper. International Centre for Sustainable Cities.

US Environmental Protection Agency. (2011). HUD-DOT-EPA Partnership for Sustainable Communities. Retrieved April 11, 2014, Websites:

http://www.epa.gov/smartgrowth/partnership/\#background

Utusan Online. (2016). 1.95 juta pekerja asing diperlukan. Retrieved Mei 3, 2016, Websites: http://www.utusan.com.my/bisnes/ekonomi/1-95-juta-pekerja-asing-diperlukan-1.307482

Valuation and Property Service Department, JPPH. (2014). Property Market Report 2014. INSPEN, Ministry of Finance Malaysia.

Victorian Competition and Efficiency Commission. (2008). A state of liveability: An enquiry into enhancing Victoria's liveability, Final report, 2008, Victorian Competition and Efficiency Commission: Melbourne, Victoria

Wan Nor Azriyati Aziz, Noor Rosly Hanif \& Singaravelloo, K. 2011. Affordable Housing Within the Middle Income Households in Malaysia: Challenge to Enter Homeownership, Australian. Journal of Basic and Applied Sciences, 5(8), 258 -267.

Wangui, N. F. (2014). Determinants of Access to Affordable Housing in Nairobi County. A Research Project. Master of Science in Finance, School of Business. University of Nairobi.

Yang, F. (2009). Consumption Over the Life Cycle: How Different is Housing? Review of Economic Dynamics, 12(3), 423-443.

Zainal Abidin Hashim. (2010). House Price and Affordability In Housing In Malaysia. Akademika, 78, 37-46

Zainal Abidin Hashim. (2010). Real Estate Market Boom In 1998 And 2008: Some Key Economic Indicators. Proceedings Perkem V., 2, $152-158$ 